\title{
On the Emotion, Sound and Rhyme of China's National Vocal Music Art
}

\author{
Xiaoying Guo
}

Department of music, Nanchang Normal University

Keywords: National vocal music; Bel Canto; Charm; Aesthetic features; Affectionately

\begin{abstract}
Chinese national vocal music art, is the art of ancient Chinese culture for thousands of years, is unique to Chinese history and culture, expression, aesthetic reflects the art of vocal music, this is our nation's own "heart songs". "Love, sound, and rhyme" is China National vocal of three big basic features, colorful of national language and brilliant of China traditional culture gave birth to has China National vocal this a flashing with Chinese spirit and wisdom of art varieties "as China National vocal art of unique of aesthetics character, they has sharp of national features and aesthetic style and spirit, is China National vocal Art aesthetics theory of a permanent subject" paper on China National vocal art of "love, and sound, and rhyme" for discussion, Precisely in order to grasp its essential basic characteristics and aesthetic theory of Chinese national vocal music art makes some preliminary explanation. This article is about the national singing is a reference to the modern music scene of this singing style is based on the traditional vocal music art, with our country's political life, life is constantly changing and constantly improve the development of, the strengths of other arts and integration and the formation of the continuous choice.
\end{abstract}

\section{Introduction}

"According to the principles of aesthetics and appreciation of the Chinese people, is good at displaying our national character, spiritual features, pronunciation and intonation, Melody feat ures the sound image and singing skills, and singing the Chinese nationalities and regions, all with a national style of vocal singing, are called folk singing. "

The national singing title talked in this paper is proposed by China's modern music circle, and this singing art develops and improves constantly with the constant change of China's political and cultural life on the basis of traditional vocal music art. To constantly choose other arts strengths and integration and the formation of the 1930s Yangko opera singing method, is the prototype of national vocal music, so to speak. Opera after the huge success of the white-haired girl, marked the beginning of Chinese national vocal music's true, it is a new era of Chinese national vocal music art development. Contemporaneous and 560 have been created and played a large number of new Opera and new folk songs. These people's new life, a new feeling, a new spirit of new musical styles and a new way of singing and added a strange light in the music.

After liberation, the music education began the teaching of national vocal music study, set up a private class, national opera troupe and the undergraduate vocal professional. From that point on into China's national vocal music art higher musical institution, and singing at the singing style, began a comprehensive and detailed study of theory and practice of teaching. Into the eighties, has been China's national vocal music art is art garden of fragrant, closely related to the lives of people of all ethnic groups, closely related to gorgeous flowers. Most Conservatory has established a "vocal" professional, in the direction of teaching, course content and teaching styles and teaching 
management are perfect.

"Love, sound and rhyme" are the three basic characteristics of China's national vocal music art, and the supreme realm of creation "sing wonderfully with a silver voice and deep feeling" is the aesthetic concept of China's national vocal music art ever since ancient times.

"Love" is the soul of singing, and a song without a soul cannot be touching. Vocal music is the art to perform with voices, so it more needs "love" to demonstrate the contents of music. Meanwhile, due to the aesthetic habit of Chinese formed by the special cultural background, society and history, we are required to adopt special way to deal with emotions while singing national songs so as to form special singing style. "To sing your feelings" is caused by your true feeling, and your sound must be able to "touch people" and produced by your true feelings. Your song has to be "charming" in order to "touch people", that is "sound produced by true feelings and love".

For singing, "sound" is the important basis. Without good sound, it is impossible to create songs for the second time. The "sound" of national vocal music is the unique sound based on the Chinese phone, so it should be on the premise of scientific methods of training, knowled ge and application of national vocal music's voice and personality and characteristics, so that its Chinese language, emotion and style unity, coordination, performance so as to meet the Chinese audience and even the audience's appreciation of the world.

"Rhyme" is the flavor, color, style, and personality. In singer's song, in the viewer's imagination, she is beauty in music listeners into realm of art material media, it gives a unique beauty.

In the actual singing, "love", "sound" and "rhyme" are never separated but they are intersected and blended and connected with each other. Then, where "emotion" in songs comes from? How it is expressed? How "rhyme" in songs are formed? How bright, crispy and concentrated "sounds" are produced? And how "love", "sound" and "rhyme" form artistic force and affect audiences?

This article from the ancestors in the music theory of the inheritance left from past and present excellence in vocal music from Musical Arts of national vocal music from "sound" cavity in pure vocal art from "rhyme" in national vocal music art to observe the essence of the problems mentioned above, and seeks to explore the correct answer.

\section{Title}

In ancient China, the earliest clear "feeling" the aesthetic concept, is a poet, eminent music critic Bai Juyi of the Tang dynasty. He wrote this happiness poem in "ask Yang Qiong": "the ancients sang and sang, people sing songs. Said June won't be, even an attempt to ask Yang Qiong. "He thinks Yang Qiong is sound and good song. But probably many singers in the Tang dynasty, pay no attention to feeling, so BAI Ju-Yi's criticism of this "sound" tendencies.

"Sing" is singing music "oriented" loss was the loss of music "this." Li Yu during the Qing dynasty said in "Xian Qing Ou Ji" that "singing but not sing. Mouth has song and surface Shang, and body no song, this so-called ruthless of song, and Mengtong endorsement, same barely and non-natural also, he said this ruthless of song for "died sound", he requirements singing who "variable died sound for live song", "have its meaning then sing, sing Shi to spirit throughout which, to chip off the" If, is same sing also, same song also, its turned cavity, and between the changes of words, don't has a sound mouth, lifted up his eyes, in retrospect, another is a site look. "Sing a song to sing, saying" good singing voice is not the best ", this means that" feeling "is the first" good singing voice, at best, only "Lark", is no aromatic flower paper flowers.

It is written at the beginning of "the Music": "sound, and also by the people. People move, make it 
so. Sense to move, so the acoustic "the meaning of this passage is: sound is produced by from the heart" the heart activity is caused by things outside of "the heart sense external things, excited the feelings, manifests itself becomes the sound".

Psychology clearly states that people's emotions are always in the know or transform the objects at the same time, take an attitude of one kind or another, which produces satisfaction and subjective experiences, love, fear, anger, disgust. From the simplest to the most complex thinking, are accompanied by emotion, without feeling there is no emotion. The deaf do not smell noise can be annoying, not the beauty of encouraging the blind "emotion is a State of the person's mood, and the art of vocal music according to mood, a voice to express the people's mental activity, the inner world of man's emotional state was like a fish in water. People of emotional, such as: parent-child love, and mother love, and couples love, and brothers love, and flesh love, and love, and comrades love, and student love, and home love, and country love, and rivers love, and parting of love, and Miss of love, and joy of love, and grief of love, and blues of love, and delight of love, and outrage of love, and complaints of love, are for since in the of love, not conversion for national vocal in the of "sound in the of love".

Mourning heart: "enforces the, temperate" (Analects), as an article important of value standard throughout Yu more than 2000 years of China Han music in the "Opera Dan Xun Huisheng, he in performances erjie was harm died Shi most bitter of that sentence aria" pain heartbroken dye sand "(Erhuang Sanban), is how produced of does? He said:" sing Shi to like Hairspring hundred turned, lingering and drag long, to seem to near shortage adjustable, said sobbing, makes audience also has soul-stirring, Pat stroke heard of feels. Only in this way can reach tragic sound effects "(the theory of Xun Hui starred in the play). This "cry" was his artistic creations in the musical "in this near-Huang tune" cry sound "voice directed to express the character of the pain off, sobbing, is both subtle and intense, is the real emotion from the song, with cavity of humans. "Reserved" comment, it says that there are some very small words: "cast when I must impress people by voice, with art moving, not only makes people listen to the good, but also so that we never tire of listening, can never tore his throat a cry at sad times."

Happy heart: to rock mouth drop for cases "songs of second segment is cheerful enthusiasm of tunes melody, added into has folk songs in the often of love performance, Express has" Mei "on to Yunnan participate in built highway of "age" "a picks a picks put mountain opened, picks mountain mill into fist sample" of proud and care, and" poor mountain into mountain, picked flower flowers to o song wearing "of very cheerful joy mood. Therefore, when singing, and singing passionate, proud happy voice jumping compact and elastic.

Glad heart: blue with the clear sparkling water's days as an example, looking forward to seeing this song is characterized by a small celery open hero will return to County of Xiao Erhei, so take laundry waiting for Xiao Erhei, her feelings are expressed through songs full of joy.

Angry heart: In expressing the emotion, pitch-tune can play an important role.

Revere heart: The song "I love you, China" is 70 late composer he and composer Di Zong for film loafers by creation of a first episode "lyrics kind rustic, and fresh beautiful, using has series of overlap sentence, and parallelism sentence, on country broad vast of mountains River and beautiful rich of pastoral crops made has system image of depicting description and carefully of metaphor praise, express author on country very of reverence and deep of sentimentally attached to.

Loving heart: National vocal music of "love" comes from the hearts of people "love", which in turn meticulously on various "moods" shape, resulting in "responsive, resonance" deep sense of "this 
is the social role of art law, and is also an objective appreciation of the beauty of music.

A culture to sing the sound choice is fundamentally based on the speech. And Italy language! English, printed Europe voice compared to, China Chinese of voice features, is pronunciation tongue bit General in the upper front, vowels resonance Center in front oral Department hard jaw Department "due to songs is music and voice integrated constitute of composite symbols system, former in generated relationship Shang by which powerful restricted, thus singing and voice of resonance Center often is same or similar of "such, on formed to Chinese voice for based of China National singing in timbre Shang of features:

1) Wall of oral hard palate, front tooth hard tissues such as columns, on acoustic reflecting strong and resonant focus near the mouth, so the sound cheerful and bright.

2) Due to the resonance of the sound before the mouth, with head and chest cavity to form triangular lines, unlike the pharyngeal cavity, as are in the middle of head and chest cavity, voice/vertical lines formed, therefore, resonated with the former is not strong.

3) Rather, pharyngeal cavity resonance range centered so complete, so fewer overtones and the volume is thin, but the sound is bright, crisp and focused. This "first" audio selection through thousands of years of practice, has accumulated sound aesthetic concepts that are common to most cultures, it's value is not in its form per se, but that it recognized by a wide audience of cultural psychology of stimulus-response utility "it is our spirit of traditional preferences and social custom, taste and language that, in line with our national aesthetic practices.

Science is in accordance with characteristics of the body's physiological function of singing, vocal organs in accordance with the meaning of words and music requirements, singing in the optimum use of the human voice with volitional control of artistic expression. Singing is a very complex process, which involves everyone's natural conditions, postnatal development, as well as aspects of breath, the words rhyme and tunes, to correct scientifically it is not an easy thing, it not only need long-term training in vocal skills and techniques, inherent temperament and cultural factors, such as the need for support.

Chinese vocal music art different from the major Western European vocal music school, one of the big factors is due to language, language differences between determines the unique characteristics of Chinese national vocal music art. Therefore, the melody of Chinese national vocal music songs with lyrics to always tone towards identical, so not enough to hear the lyrics. In a rhyme sound of folk singing, regardless of dialect, require "articulation" clear and pure. TraditionalChinese vocal emphasis on "cavity", says is the truth. "Character" is always the first, only in "word" based on the "cavities" makes sense. Word is, should the Chamber ran express meaning.

"Charm" is China of a traditional of aesthetics concept, history are has scholar on the and the "it has unique of national style features" as a aesthetics concept, it not only refers to of is literary works of beauty of realm, and main is refers to aesthetic main object of an aesthetic feel and contact, meaning that for far-reaching, and implicit and has means of, can caused emotional Shang of long resonance, makes played who and appreciate who are can obtained beauty of a species feel "in singer of song in the, in appreciate who of imagine in the, Flavor is to music listeners showed the beauty of art material media, this mood is aroused by the song, charm of "Confucius of the so-called" March don't know meat taste ", referring to the music's charm have always kept him so that he could not forget for a long time," music "," meat ".

What is meant by "tune"? Tune, is the folk music (including music) performing artists, when they sing or play music with Chinese national style and characteristics (ARIA), may touch on it and 
decorate, making it stronger, full of color, style, rich in flavor of the perfect work of art.

Chinese national vocal music has always been exquisite charm and accustomed to using a flavor of bias as an important criterion for evaluating the level of singing. Rhyme of cavities, rhymes and singing the rhyme color skills to form a rhythmic cadences of national vocal music, entangle the fibers hold knots, increasing important reason for musical expression and artistic appeal. This melodic decoration and make the comparison of timbre, dynamics and speed and in relative stability in a rapidly changing, so we tune sample method is rich and colorful, with million. Some of these skills in unique and chic in the world is also one of the few vocal art. Mainly in the following ways:

1) Decorative music-singing method

2) Broken melody even moist tuning method

3) Tuning method of sound changes

4) Tuning Method of Strength Changes

5) Tuning Method of Sound Style

6) An important means of changes in tempo and speed to polishing and processing is also singing music performance.

7) Others. Sometimes slightly slow, slightly faster, and also reduction, which is often, but the singer must heart, there must be conducive to the singing performance, and freedom, do not casually, the destruction of the concert.

In the actual vocals, "sentiment, sound, rhyme" is always cross integrate, combine together, sections of this paper before the analysis of the "feeling", "sound", "rhyme", just for the convenience of narration temporarily separate to talk about "sentiment, sound, rhyme "in the interpretation of the singer is according to what principle, what rules combined in together? After binding to and what results? It is precisely what we should explore to understand the deeper "this can from the" love "," sound "," Rhyme "three different perspectives.

\section{Conclusions}

The creation of Chinese national vocal music art "charm beauty" is difficult to achieve only by feeling, sound and rhyme. Even if a certain part of the artistic level, then the performance of the charm is still only an incomplete beauty. In fact, the relationship between the three and the "charm beauty" is the relationship between the local and the whole. They depend on each other, influence each other; therefore, sentiment, sound and rhyme only mutual coordination, mutual cooperation, mutual accommodation, is close to the sweet feeling, vivid and emotional charm beauty.

So far, China has formed national vocal music art styles, colorful boom, this is success and pride of national vocal music art. But because our country is vast in many ethnic groups, in terms of the development of national art of singing, both common character, both borrowed from each other for common development also has its own national characteristics, independent aspect of the development of "folk singing, constantly absorbing in its training and singing Bel Canto vocal method to develop and enrich itself and has achieved remarkable results. However, the vocal to the pursuit of a high artistic level, must also maintain its artistic features of the premise, continued research and absorb the advanced method of singing, to establish scientific training system in line with their own characteristics so as to accommodate more high requirements of art appreciation. 


\section{References}

[1] Pavlicevic M. Improvisation in music therapy: Human communication in sound[J]. Journal of Music Therapy, 2000, 37(4): 269-285.

[2] Grinde B. A biological perspective on musical appreciation[J]. Nordisk Tidsskrift for Musikkterapi, 2000, 9(2): 18-27.

[3] Perris A. Music as Propaganda: Art at the Command of Doctrine in the People's Republic of China[J]. Ethnomusicology, 1983: 1-28.

[4] Crowe B J, Scovel M. An overview of sound healing practices: Implications for the profession of music therapy[J]. Music Therapy Perspectives, 1996, 14(1): 21-29.

[5] Simmel G. Psychological and Ethnological Studies on Music1[J]. The Routledge Reader on the Sociology of Music, 2015: 35.

[6] Chen-Hafteck L. In search of a motivating multicultural music experience: lessons learned from the Sounds of Silk project[J]. International Journal of Music Education, 2007, 25(3): 223-233.

[7] Hung C T. The politics of songs: myths and symbols in the Chinese Communist war music, 1937-1949[J]. Modern Asian Studies, 1996, 30(04): 901-929.

[8] Whalley I. Software Agents in Music and Sound Art Research/Creative Work: current state and a possible direction[J]. Organised Sound, 2009, 14(02): 156-167.

[9] Friedlander P. China's" Newer Value" Pop: Rock-and-Roll and Technology on the New Long March[J]. Asian Music, 1991: 67-81.

[10] Bresler L. The genre of school music and its shaping by meso, micro, and macro contexts[J]. Research Studies in Music Education, 1998, 11(1): 2-18. 